\title{
Association of Copper-to Zinc Ratio with Sperm Concentration among Males Investigated for Infertility
}

\author{
Mathias Abiodun Emokpae* and Muyiwa Adeleye Moronkeji \\ Department of Medical Laboratory Science, School of Basic Medical Sciences, College of Medical Sciences, University of Benin, Benin City, Nigeria
}

Received: 28/07/2020 Accepted: 13/09/2020 Published: 20/09/2020

\begin{abstract}
Background: The importance of copper and zinc in the fertility potential of males are well understood. The close relationship and the antagonistic interactions between copper and zinc requires further investigation especially because of conflicting reports in literature on the association of the trace elements with sperm quantity and quality. This study evaluates seminal plasma copper and zinc concentrations, copper-to-zinc ratio and their associations with sperm concentration in infertile males.

Methods: This is a cross-sectional study of 400 males investigated for infertility and 100 male control subjects. Seminal plasma copper and zinc were determined using atomic absorption spectrophotometry technique (Buck Scientific Model VGP-210, Germany). The subjects were grouped based on sperm count; normozoospermia $\left(>15 \times 10^{6} \mathrm{cells} / \mathrm{mL}\right)$, oligozoospermia $\left(<15 \times 10^{6} \mathrm{cells} / \mathrm{mL}\right)$ and azoospermia (no sperm cell). The levels of copper, zinc and Cu/Zn ratio were compared using unpaired Students-t-test and analysis of variance while Pearson correlation coefficient was used to assess the correlation between measured variables and sperm count.

Results: Seminal plasma zinc was significantly lower $(p<0.001)$ while copper and $\mathrm{Cu} / \mathrm{Zn}$ ratio were significantly higher $(\mathrm{p}<0.001)$ in infertile than fertile males. The $\mathrm{Cu} / \mathrm{Zn}$ ratio was significantly higher $(\mathrm{p}<0.001)$ among infertile males than controls. Seminal plasma levels of copper and $\mathrm{Cu} / \mathrm{Zn}$ ratio increased with decreasing concentrations of sperm cells while zinc levels increase with increasing concentration of sperm cells.

Conclusion: Copper-to-zinc ratio correlated with sperm concentration in infertile males. The interaction between copper and zinc may be routinely considered in the clinical evaluation of the infertile men.
\end{abstract}

Keywords: Copper, Zinc, Sperm concentration, Male infertility

\section{Introduction}

Copper-to-zinc $(\mathrm{Cu} / \mathrm{Zn})$ ratio may be a good indicator of male fertility potential. The evaluation of the relationship between $\mathrm{Cu} / \mathrm{Zn}$ ratio and sperm indices in seminal plasma may give a better understanding of the mechanisms underlying male infertility. Deficiency of $\mathrm{Zn}$ in the reproductive system can lead to hypogonadism and gonadal hypofunction (1). Several authors have shown the physiologic role zinc plays in the development of testicles, prostate and sperm motility (2, 3). Zinc and copper have very close relationship and their interactions are majorly antagonistic (4). Appropriate concentrations are needed for adequate physiological functions (5). Any variation from normal of either of the trace element will disrupt the equilibrium and affect the $\mathrm{Cu} / \mathrm{Zn}$ ratio which may ultimately impact the fertility potential of the male. Some authors have indicated a range for the ratio of $\mathrm{Cu} / \mathrm{Zn} 0.9$ to 1.27 and this may be different with different semen abnormalities (6).

Zinc is the second most abundant trace element in human body, it cannot be stored. It therefore needs to be regularly replenished via the diet. The importance of $\mathrm{Zn}$ in human reproductive health and its potential in sperm quality and quantity requires regular evaluation especially in the subSaharan Africa where the rates of infertility and micronutrient

*Correspondence author: Prof. M. A. Emokpae, Department of Medical Laboratory Science, School of Basic Medical Sciences, College of Medical Sciences, University of Benin, Benin City, Edo State, Nigeria. Email: mathias.emokpae@uniben.edu,_Cell Phone: +2348034511182 deficiencies are high. The seminal plasma contains several elements such as copper, zinc, and Iron that protect the spermatozoa at the time of ejaculation (8). Zinc deficiency may be an important risk factor for poor quality and quantity of sperm and idiopathic male infertility (9). Zinc is required for adequate physiological function of the body such as growth, reproduction, DNA synthesis and repair, cell division and gene expression, wound healing and immune function (10). In humans, the level of zinc is high in the prostate compared to the other tissues and body fluids. Zinc is a marker of prostatic function and it regulates the functions of spermatozoa, acts as a co-factor for several enzymatic reactions, and helps in the preservation of sperm motility (11). It has been reported that most of the copper present in seminal plasma comes from the prostate, but unlike zinc, copper is also released by other structures of the reproductive tract such as epididymis and seminal vesicles (11). Copper is an important trace element for several metalloenzymes and metalloproteins that are involved in energy or antioxidant metabolism. Unfortunately, the ionic form of copper rapidly becomes harmful to many cells at high levels, including human spermatozoa. Copper can promote the formation of free radicals and induce the oxidation of polyunsaturated fatty acids of membrane leading to the inactivation of enzymes and structural proteins abnormalities (12). There are however conflicting reports in literature as to the impact of low or high levels of copper or zinc on semen quantity and quality. Some have shown that oligozoospermic men with sperm counts $<20$ million per mililiter had slightly lower seminal plasma zinc level than normozoospermia, while others observed that 
normozoospermic and oligoasthenozoospermic males had similar seminal plasma zinc levels (13-15). A low Zn levels in cells was reported to be a contributing factor to poor sperm quality and testosterone in infertile males (16), while Danscher et al (17) reported a high concentration of $\mathrm{Zn}$ was associated with poor sperm motility. Experimental study has shown that low copper level may be lead to the production of ejaculates of lower volume, lower sperm concentration and poor sperm motility and morphology (6). On the other hand, some authors have reported that high $\mathrm{Cu}$ levels were harmful to reproductive function and $\mathrm{Zn}$ had an opposite influence on the semen quality (19). Despite the numerous studies of the levels of $\mathrm{Cu}$ and $\mathrm{Zn}$ only very few had associated $\mathrm{Cu} / \mathrm{Zn}$ ratio with sperm indices among infertile males. This study seeks to determine the levels of $\mathrm{Cu}$ and $\mathrm{Zn}$ concentrations in seminal plasma of infertile men and correlates $\mathrm{Cu} / \mathrm{Zn}$ ratio with sperm concentrations.

\section{Materials and Methods \\ 2.1 Study Design}

This is a cross-sectional study of males investigated for infertility and the study participants were between the ages of 23-60 years with mean age of $40.4 \pm 5.6$ years. The control group were males of proven fertility without chronic clinical illnesses with mean age of $40.2 \pm 5.5$ years.

\subsection{Ethical Consideration}

The study protocol was approved by the Health Research Ethics Committee of Osun State Ministry of Health, Abere, Osogbo, Osun State (Ref. OSHREC/PRS/569/149) dated 30 th November, 2017. All study participants gave informed consent before specimens were collected.

\subsubsection{Inclusion Criteria}

All male subjects evaluated for infertility and consented to be enrolled without physical abnormalities or chronic illnesses were included in the study. Subjects without chronic clinical illnesses and had their babies within the last one year, whose semen counts were over 15 million sperm cells per millilitre semen according to World Health Organization (WHO) criteria (19) were included and used as controls.

\subsubsection{Exclusion Criteria}

Individuals with known pathological or congenital conditions such as hypertension, diabetes mellitus, sexually transmitted diseases, testicular varicocele and genital warts were excluded. In addition, individuals currently on antioxidant supplementation, smokers and alcoholics were also excluded.

\subsection{Sample Collection}

Semen samples were collected in a sterile container by self or assisted masturbation after at least 72 hours of sexual abstinence (without the use of spermicidal lubricants). The specimens were delivered to the laboratory within 30 minutes of ejaculation. Two specimens were collected at different visits within two months for analysis and mean value of the determinations was used.

\subsection{Laboratory Analysis}

\subsubsection{Routine Semen Analysis}

After liquefaction the semen specimens were assessed for volume, appearance, $\mathrm{pH}$, and viscosity. Routine semen analysis was performed microscopically with special interest in the sperm concentration, percentage motility and percentage morphology. Based on the sperm concentration/count according to WHO criteria (19), the overall samples were therefore grouped into the following categories: normospermia; $\geq 15 \quad \times 10^{6}$ cells $/ \mathrm{mL}$, oligozoospermia; 1-14.9 x $10^{6}$ cells $/ \mathrm{mL}$, and azoospermia; absence of sperm cells in the ejaculate. After analysis, the semen specimen was centrifuged at 3000rpm for 10 minutes and the supernatant was separated and used for $\mathrm{Cu}$ and $\mathrm{Zn}$ determination.

\subsubsection{Determination of $\mathrm{Cu}$ and $\mathrm{Zn}$ concentrations}

Total seminal plasma copper concentration was measured by atomic absorption spectrometry (Buck Scientific Model VGP-210, Germany). Samples were digested by adding nitric acid diluted with deionized water (1:4). This was aspirated into the instrument after adequate calibration with series of $\mathrm{CuCl}_{2} \cdot \mathrm{H}_{2} \mathrm{O}$ standards at wavelength of $324.8 \mathrm{~nm}$.

\subsubsection{Determination of zinc}

Zinc concentration in seminal plasma was measured by atomic absorption spectrophotometry (Buck Scientific Model VGP-210, Germany) at a wavelength of $213 \mathrm{~nm}$. Before each assay, specimen was diluted 1:4 and mixed thoroughly. The instrument was calibrated with $\mathrm{Zn}$ standard solutions. The spectrophotometer was calibrated after each series of assays.

\subsection{Statistical Analyses}

The data were compared between the groups using unpaired Students-t-test and One way analysis of variance (ANOVA) as appropriate by statistical software SPSS version 21 (SPSS Inc, Chicago, IL, USA). A p-value $\leq 0.05$ was considered statistically significant.

\section{Results}

Table 1 shows the comparison of seminal plasma levels of copper, zinc and $\mathrm{Cu} / \mathrm{Zn}$ ratio among infertile males than fertile males. Seminal plasma zinc was significantly lower $(p<0.001)$ while copper and $\mathrm{Cu} / \mathrm{Zn}$ ratio were significantly higher $(p<0.001)$ in infertile than fertile males. In the same vein, $\mathrm{Cu} / \mathrm{Zn}$ ratio was significantly higher $(\mathrm{p}<0.001)$ among infertile males than controls. Seminal plasma levels of copper and $\mathrm{Cu} / \mathrm{Zn}$ ratio increased with decreasing concentrations of sperm cells while zinc levels increase with increasing concentration of sperm cells among infertile males (table 2). Table 3 indicates that copper and $\mathrm{Cu} / \mathrm{Zn}$ ratio correlated negatively while zinc correlated positively with sperm concentrations.

Table 1: Comparison of seminal plasma levels of copper, zinc and copper-to-zinc ratio in infertile males

\begin{tabular}{|l|l|l|l|}
\hline Parameters & Infertile males $(\mathrm{n}=400)$ & Fertile males $($ Controls $)(\mathrm{n}=100)$ & P-value \\
\hline Age $($ Years $)$ & $40.4 \pm 5.61$ & $40.2 \pm 5.60$ & 0.91 \\
\hline Zinc $(\mu \mathrm{g} / \mathrm{mL})$ & $0.81 \pm 0.01$ & $2.06 \pm 0.08$ & 0.001 \\
\hline Copper $(\mu \mathrm{g} / \mathrm{mL})$ & $1.41 \pm 0.08$ & $1.93 \pm 0.05$ & 0.001 \\
\hline Copper-to-zinc ratio & $1.73 \pm 0.01$ & $0.92 \pm 0.02$ & 0.001 \\
\hline
\end{tabular}


Table 2: Comparison of copper, zinc and copper-to-zinc ratio among subtypes of infertile males

\begin{tabular}{|l|l|l|l|l|}
\hline Subtypes of infertility & $\mathrm{N}$ & $\begin{array}{l}\text { Seminal plasma } \\
\text { copper( } \mu \mathrm{g} / \mathrm{mL})\end{array}$ & $\begin{array}{l}\text { Seminal plasma } \\
\text { zinc }(\mu \mathrm{g} / \mathrm{mL})\end{array}$ & $\begin{array}{l}\text { Copper-to-zinc } \\
\text { ratio }\end{array}$ \\
\hline Azoospermia(Absence of sperm cells) & 41 & $2.73 \pm 1.48^{\mathrm{b}}$ & $0.92 \pm 0.61^{\mathrm{b}}$ & $2.95 \pm 0.02^{\mathrm{b}}$ \\
\hline Oligozoospermia $\left(<15 \times 10^{6} / \mathrm{mL}\right)$ & 168 & $1.97 \pm 1.62^{\mathrm{a}}$ & $1.26 \pm 0.81^{\mathrm{b}}$ & $1.56 \pm 0.01^{\mathrm{b}}$ \\
\hline Normozoospermia $\left(>15 \times 10^{6} / \mathrm{mL}\right)$ & 191 & $1.95 \pm 1.39$ & $3.08 \pm 0.59$ & $0.62 \pm 0.01$ \\
\hline P-value & 400 & 0.001 & 0.01 & 0.001 \\
\hline
\end{tabular}

$a=p>0.05 ; b=p<0.001$

Table 3: Correlation of seminal plasma copper, zinc and copper-to-zinc ratio with sperm concentrations

\begin{tabular}{|c|c|c|c|c|c|c|}
\hline Correlation & $\begin{array}{l}\text { Copper } \\
\text { R-value }\end{array}$ & P-value & $\begin{array}{l}\text { Zinc } \\
\text { R-value }\end{array}$ & P-value & $\begin{array}{l}\mathrm{Cu} / \mathrm{Zn} \mathrm{R} \\
\mathrm{R} \text {-value }\end{array}$ & $\begin{array}{l}\text { o } \\
\text { P-value }\end{array}$ \\
\hline Normozoospermia & -0.160 & 0.05 & 0.187 & 0.01 & -0.155 & 0.01 \\
\hline Oligozoospermia & -0.59 & 0.05 & 0.221 & 0.005 & -0.244 & 0.002 \\
\hline Azoospermia & -0.359 & 0.02 & 0.310 & 0.02 & -0.492 & 0.001 \\
\hline
\end{tabular}

\section{Discussion}

The conflicting reports in literature coupled with the importance of biological functions of copper and zinc in reproductive health, it is important to assess the $\mathrm{Cu} / \mathrm{Zn}$ ratio in the assessment of their association with sperm concentration. The $\mathrm{Cu} / \mathrm{Zn}$ ratio is a more important assessment than the concentration of individual element in clinical practice. In healthy individuals, the body has the ability to manage and regulate the amount of essential trace elements in the blood. The dietary essential metals are included into blood if their blood concentrations are low, incorporated into the cells when their cellular levels are depleted or eliminated when blood and cellular levels are adequate or excess (20). When this regulatory system fails to function optimally, abnormal levels and imbalance in their ratios occur (21).

In this study, we observed that seminal plasma copper and $\mathrm{Cu} / \mathrm{Zn}$ ratio were significantly higher while zinc was significantly lower in infertile males than fertile control subjects. This observation is consistent with previous studies (9, 21-24). Zhao and Xiong reported a lower mean level of zinc and a positive association with poor spermatogenesis and poor sperm quality among infertile men (22). Also, Chia et al reported that seminal plasma zinc levels correlated directly with sperm density and motility (23). A significantly low level of seminal plasma zinc was reported in oligozoospermia and azoospermia and that poor zinc in diet is a risk factor for low sperm quality of sperm and idiopathic infertility (9). Conversely, other authors observed that no significant correlation exist between zinc concentration and semen indices $(25,26)$.

Zinc plays important roles in the physiological functions of spermatozoa. The zinc finger motif Cys $2 / \mathrm{His} 2$ of protamine plays vital role in the prevention of transcription via sperm chromatin stabilization and in the prevention of oxidative damage. Also, zinc is a cofactor for antioxidant enzymes (7). Zinc protects the testes from injury by stressors such as toxic metals, fluoride and heat (7). It is accumulated in the testes during early spermatogenesis and probably plays a role in the modulation of spermatogonial proliferation and differentiation (7). The impact of low seminal plasma zinc on fertility also stem from its effect on the hypothalamus-pituitary-gonadal axis. Low zinc has adverse effect on serum testosterone secretion. Adult males with low zinc levels had inadequate testosterone synthesis in the leydiq cell, because zinc is cofactor for $5 \alpha$-reductase enzyme that is necessary for the transcription of testosterone to the biologically active form,
$5 \alpha$-dihydro-testosterone (7). The finding of significantly higher copper levels in seminal plasma of infertile men is consistent with previous studies (27-29). The authors observed that copper chelation was implicated in the suppression of spermatogenesis suggesting that higher levels are harmful to reproductive potential. Experimental study has indicated that implantation of copper in the epididymis, vas deferens and scrotum of mammals adversely affected fertility, hence copper was considered as a highly toxic element for sperm (30). High levels of copper in seminal plasma were associated with decreased sperm motility. An action that was attributed to induction of free radicals generation by copper ions,that ultimately resulted in lipid peroxidation of spermatozoa membrane (27). Copper-to-zinc ratio correlated with sperm concentration, finding that is consistent with previous study (6). Significantly higher $\mathrm{Cu} / \mathrm{Zn}$ ratio was reported among subjects with abnormal progressive motility than that of the healthy control group. Higher $\mathrm{CU} / \mathrm{Zn}$ ratio was also reported among subjects with poor sperm quality than normozoospermia. Low serum zinc, higher copper levels and higher $\mathrm{Cu} / \mathrm{Zn}$ ratio were reported among infertile men than fertile control subjects $(30,31)$.

\section{Conclusion}

Significantly higher seminal plasma copper and $\mathrm{Cu} / \mathrm{Zn}$ ratio coupled with lower zinc was observed among infertile males than control. Copper-to-zinc ratio correlated with sperm concentration in infertile males. The interaction between copper and zinc may be considered in the clinical evaluation of the infertile men.

\section{Acknowledgments}

The authors appreciate the contributions of all medical, Nursing and Medical laboratory services Departments towards the completion of the study.

\section{Source of funding}

Nil

\section{Ethical issue}

Authors are aware of, and comply with, best practice in publication ethics specifically with regard to authorship (avoidance of guest authorship), dual submission, manipulation of figures, competing interests and compliance with policies on research ethics. Authors adhere to publication 
requirements that submitted work is original and has not been published elsewhere in any language.

\section{Competing interests}

The authors declare that there is no conflict of interest that would prejudice the impartiality of this scientific work.

\section{Authors' contribution}

All authors of this study have a complete contribution for data collection, data analyses and manuscript writing.

\section{References}

1. Trang NT, Sang TT, Hoang N, Khanh NTG, Duc TT. Assessment of the level of seminal zinc and fructose concentration in seminal plasma of Vietnamese infertile men. MOJ Biorg Org Chem. 2018;2(4):185-190.

2. Biswas S, Ferguson KM, Stedronska J, et al. Fructose and hormone levels in semen: their correlations with sperm counts and motility. Fertil Steril. 1978;2(30):200-204.

3. Saleh BOM, Hussain NK, Majid AY, et al. Status of Zinc and Copper Concentrations in Seminal Plasma of Male Infertility and Their Correlation with Various Sperm Parameters. The Iraqi postgraduate Med J.2008;7(1):76-80.

4. Kedi Y. Trace element and health. Beijing: Science Publication House, 2003:1, 49.

5. Burns J, Paterson CR. Effect of iron-falate supplement-tation on serum copper concentration in late pregnancy. Acta Obstet Gynecol Scand 1993;72:616-8.

6. Yuyan L, Junqing W, Wei Y, Weijin Z, Ersheng G. Are serum zinc and copper levels related to semen quality? (Fertil Steril_ 2008;89:1008-1011.

7. Fallah A, Mohammad-Hasani A, Hosseinzadeh Colagar A. Zinc is an Essential Element for Male Fertility: A Review of Zn Roles in Men's Health, Germination, Sperm Quality, and Fertilization. J Reprod Infertil. 2018;19(2):69-81.

8. Khosronezhad N, Hosseinzadeh Colagar A, Mortazavi SM. The Nsun7 (A11337)-deletion mutation, causes reduction of its protein rate and associated with sperm motility defect in infertile men. J Assist Reprod Genet. 2015;32(5):807-815.

9. Colagar AH, Marzony ET, Chaichi MJ. Zinc levels in seminal plasma are associated with sperm quality in fertile and infertile men. Nutr Res. 2009;29(2):82-88.

10. Prasad AS. Discovery of human zinc deficiency: its impact on human health and disease. Advances in Nutrition. Adv Nutr. 2013;4(2):176-190.

11. Kasperczyk A, Dobrakowski M, Czuba ZP, Kapka-Skrzypczak L, Kasperczyk S. Environmental exposure to zinc and copper influences sperm quality in fertile males. Ann Agric Environ Med. 2016; 23(1): 138-143.

12. Aydemir B, Kiziler AR, Onaran I, Alici B, Ozkara H, Akyolcu MC.Impact of $\mathrm{Cu}$ and $\mathrm{Fe}$ concentrations on oxidative damage in male infertility. Biol Trace Elem Res. 2006; 112(3): 193-203.

13. Carpino A, Siciliano L, Petroni M, De Stefano C, Aquila S, Ando $\mathrm{S}$, et al. Low seminal zinc bound to high molecular weight proteins in asthenozoospermic patients: evidence of increased sperm zinc content in oligoasthenozoospermic patients. Hum Reprod. 1998;13(1):111-114.

14. Wong WY, Flik G, Groenen PM, Swinkels DW, Thomas CM, Copius-Peereboom JH, et al. The impact of calcium, magnesium, zinc, and copper in blood and seminal plasma on semen parameters in men. Reprod Toxicol. 2001;15(2):131-136.

15. Lin YC, Chang TC, Tseng YJ, Lin YL, Huang FJ,Kung FT, et al. Seminal plasma zinc levels and sperm motion characteristics in infertile samples. Chang Gung Med J. 2000;23(5):260-266.

16. Akinloye O, Abbiyesuku FM, Oguntibeju OO, Arowojolu AO, Truter EJ. The impact of blood and seminal plasma zinc and copper concentrations on spermogram and hormonal changes in infertile Nigerian men. Reprod Biol. 2011;11(2):83-98
17. Danscher G, Hammen R, Fjerdingstad E, Rebbe H. Zinc content of human ejaculate and the motility of sperm cells. Int $\mathbf{J}$ Androl. 1978;1(1-6):576-581.

18. Peizhi H, ShijuW, Xu'e L. General chemistry. Beijing: Science Publish House, 2001:372-379.

19. WHO laboratory manual for the examination and processing of human semen. 5th ed. WHO Press, World Health Organization, 20 Avenue Appia, 1211 Geneva 27, Switzerland; 2010. p. 7-113.

20. Osredkar, J.; Sustar, N.J. Copper and zinc, Biological role and significance of copper/zinc imbalance. J. Clin. Toxicol. 2011; S3:001.

21. Emokpae MA, Fatimehin EB. Copper-to-Zinc Ratio Correlates with an Inflammatory

22. Marker in Patients with Sickle Cell Disease Sci 2019; 1: 55

23. Zhao R, Xiong CL. Zinc content analysis in serum,seminal plasma and spermatozoa of asthenozoospermic and oligoasthenozoospermic patients. Zhonghua Nan Ke Xue. 2005;11(9):680-682

24. Chia SE, Ong CN, Chua LH, Ho LM, Tay SK.Comparison of zinc concentrations in blood and seminal plasma and the various sperm parameters between fertile and infertile men. J Androl. 2000; 21(1):53-57.

25. Henkel R, Bittner J, Weber R, Hüther F, Miska W.Relevance of zinc in human sperm flagella and its relation to motility. Fertil Steril. 1999;71(6):1138-1143.

26. Eggert-Kruse W, Zwick EM, Batschulat K, Rohr G, Armbruster FP, Petzoldt D, et al. Are zinc levels in seminal plasma associated with seminal leukocytes and other determinants of semen quality? Fertil Steril. 2002;77(2):260-269.

27. Lin YC, Chang TC, Tseng YJ, Lin YL, Huang FJ, Kung FT, et al Seminal plasma zinc levels and sperm motion characteristics in infertile samples. Chang Gung Med J. 2000;23(5):260-266.

28. Eidi M, Eidi A, Pouyan O, Shahmohammadi P, Fazaeli R, Bahar M. Seminal plasma levels of copper and its relationship with seminal parameters . Iran J Reprod Med, 2010; 8 (2): 60-65.

29. Viarengo A, Pertica M, Mancinelli G, Burlando G, Canesi L, Orunesu M. In vivo effects of copper on the calcium homeostasis mechanism of mussel gill cell plasma membranes. Comp Biochem Physiol C Comp Pharmacol 1996; 113: 421-425.

30. White SL, Rainbow PS. On the metabolic requirements for copper and zinc in mollusks and crustaceans. Mar Environ Res 1985; 16: 215-229.

31. Skandhan KP. Review on copper in male reproduction and contraception. Rev Fr Gynecol Obstet 1992; 87: 594-598.

32. Sharp RM, Skakkebeak NE. Are oestrogenes involved in falling sperm counts and disorders of the male reproductive tract? Lancet 1993; 341: 1392-1395. 